\title{
SOME CONTRADICTIONS IN THE CURRENT MANAGEMENT STUDIES
}

\author{
Jaroslav Komárek ${ }^{1 凶}$ \\ ${ }^{1 \bowtie}$ Department of Management, Karel Englis College, Mezírka 775/1, Brno, 602 00, The Czech Republic, +420 737 585 694, jaroslav.komarek@vske.cz
}

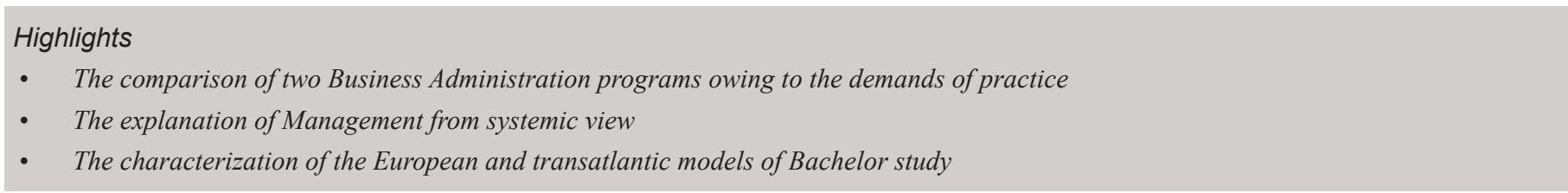

\section{Abstract}

Domestic higher studies are criticised for their low efficiency owing to the demands of practice. The core of problem is supposed in the small share of practical preparation mainly, but another cause can be the concept itself. Management studies are still considered as a part of Business Economics compared with independent study programs of Management abroad. Business Economics and Management have undergone divergent evolution during past fifty years; the Business Economics has stayed nearly unchanged and the Management has developed into a number of separate specific disciplines. While in Europe the study program Management is classified under Business \& Economics usually, independent Bachelor's and Master's degree programs are extended overseas, and common is also Doctoral study program in both on the preparation for specific professional skills and always for the line management with respect to anticipated staffing positions. Some change can bring the intended transfer of accreditation competencies, but when regarding the proposed content of Areas of Education, there is no good news for the domestic practice there. Neither the requirements for professional or academic programs are distinguished, nor adequate managerial skills mentioned.

\section{Keywords}

Bachelor study, business economics, efficiency, demands of practice, general management, management

Komárek J. (2015) "Some Contradictions in The Current Management Studies", Journal on Efficiency and Responsibility in Education and Science, Vol. 8, No. 3, pp. 67-71, online ISSN 1803-1617, printed ISSN 2336-2375, doi: 10.7160/eriesj.2015.080303.

\section{Introduction}

The quarter of a century in the new social-economic environment entitles to look back, but at the same time encourages reflecting on how to proceed. No coincidence that previously appeared critical reflections how the transfer of Management teachings from the world of market economy had contributed (Košturiak, 2005). In the recent years, however, gain contributions that the home state of the Management teachings assess negatively and point to the lack of support for the practice by theory. Bookstores are indeed full of other books on management, but those from abroad bring more stories than the methods and that domestic ones recycle generally known knowledge, sometimes not fully understood (Souček, 2012). Questions about the current and especially future development of the Management teachings are relevant also in the environment of traditional market economy. There are opinions that the development of Management is similar to that of many other phenomena logistic curve (Hamel, 2009). The influence of the first methods on productivity was significant, while the influence of a multitude of postmodern approaches, which quickly spread and were soon replaced by „more successful”, has been problematic one. Even more significant is domestic criticism directed to education because it does not meet the needs of the labour market and does not prepare properly managers (Co, 2013). These views are often subjective opinions of practice, but they are also supported by objective evaluation. Current study The needs of employers and readiness of school leavers (Úlovec, 2014) is based on more than one thousand questionnaires completed by employers from various practice areas. Employers look on the preparation of college students mainly negatively and affirm that graduate-level academic institutions are not adequately preparing students for practice. So, is the problem in the unsatisfactory efficiency of current Management Studies?

\section{The higher education of managers in the Czech Republic}

How are actually prepared graduates in Management for the crucial area of the first application in practice, namely for the position of line manager? Some specific management study program for bachelor's degree does not exist, codified is the economic study program Economics and Management, in which are accredited various fields of managerial focus. The concept of the program is based on the principle that Management is an integral part of business and thus of the teaching of Business Economics.

The origin of the Business Economics approach is in German environment, which until recently has been reluctant to accept the term Management. Wöhe's Introduction to Business administration teachings (1960) presents a comprehensive view of all business decisions undertaken in the enterprise, including basic theoretical rationale and overview of the methods used. This book therefore includes decisions on corporate objectives and form, method of manufacturing and appreciation, and just corporate administration (planning and decision making, organization, human resources management, control, and information management). But such corporate administration 
does not feature leadership and therefore not all of what is generally regarded as the content of Management. Nota bene the leadership is taken for the most important and as well the most difficult managerial activity at all.

Because Management is considered in business administration's approach as a part of economic science includes study program Economics and Management obligatory quota of mainly theoretical economic courses. To make this approach more consistently applied, the Accreditation Commission (2013) approved The standards for study programs in the field of applied management in the following interpretation: „Applied management means degree studies that combine specific professional disciplines (engineering, agriculture, arts etc.) with the education of experts in the (economics and) management. In addition to the management in the certain theoretical level supplemented with methods and techniques of management, human resources management, management skills and the basics of psychology and sociology, must be included other economic subjects - Principles of Economics, Marketing, Law (as the Basics of Law) or Statistics". Principles of Economics are but Microeconomics and Macroeconomics, and the question is how memorizing dozens of macroeconomic graphs (some valid just to another Nobel laureate in Economics) will contribute to the success of the business. But if had been included in all the non-economic fields of study Fundamentals of Business Economics, so it would contribute to increasing the international competitiveness more than ten thousand partial projects of the Operational Program Education for Competitiveness funded in amount of CZK 52 billion (Komárek, 2014).

Study programs focused on entrepreneurship have similar content abroad, but the emphasis on the practical application of theoretical background and training in managerial skills. As an example of modern European management study can be mentioned a three-year Bachelor program Business Administration (with the focus on management positions at the small and middle level enterprise) offered by the Business School Berlin Potsdam (Business, 2009). If it is compared with the corresponding program Business Economics and Management offered by the Prague Faculty of Business Administration (Fakulta, 2014), significant differences are evident (Table 1). The structure of these programs as a whole is not easily comparable (e.g. foreign languages, State exam, projects), but it is obvious a greater workload for theoretical courses in Prague program (141:110). The program of Berlin includes courses focused in more detail on practical application and especially two projects (30 credits) for real contracting authority, solved partially in practice, and thereafter in practice implemented. Predominantly theoretical focus of the Prague program is even more apparent when the form of courses is considered. The courses such as Management, Marketing, Consumer Behavior and Psychology and Sociology are lectured only and so without exercises (Fakulta, 2014).

\begin{tabular}{|c|c|c|c|}
\hline \multicolumn{2}{|c|}{ Business School Berlin Potsdam } & \multicolumn{2}{|l|}{$\begin{array}{l}\text { Prague Faculty of Business } \\
\text { Administration }\end{array}$} \\
\hline \multicolumn{4}{|l|}{ Basic courses } \\
\hline Course & Credits & Course & Credits \\
\hline $\begin{array}{l}\text { Basics of Planning and } \\
\text { Control }\end{array}$ & 5 & Management & 4 \\
\hline Basics of of Organizing & 5 & Operational Management & 6 \\
\hline $\begin{array}{l}\text { Basics of Personnel and } \\
\text { Leadership }\end{array}$ & 5 & Personnel Management & 6 \\
\hline Elective subject & 5 & $\begin{array}{l}\text { Quality, Environment, } \\
\text { Health and Safety } \\
\text { Management } \\
\end{array}$ & 3 \\
\hline $\begin{array}{l}\text { Basics of National } \\
\text { Economy }\end{array}$ & 10 & Macroeconomics & 6 \\
\hline $\begin{array}{l}\text { Basics of Business } \\
\text { Economics }\end{array}$ & 5 & Microeconomics & 6 \\
\hline $\begin{array}{l}\text { Economic Policy and } \\
\text { Globalization }\end{array}$ & 5 & Business Economics & 6 \\
\hline Financing and Investment & 10 & Corporate Finance & 6 \\
\hline \multirow[t]{4}{*}{$\begin{array}{l}\text { Accounting and } \\
\text { Controlling }\end{array}$} & 10 & Accounting & 5 \\
\hline & & Managerial Accounting & 6 \\
\hline & & $\begin{array}{l}\text { International Business } \\
\text { Operations }\end{array}$ & 3 \\
\hline & & $\begin{array}{l}\text { Banking Products and } \\
\text { Operations }\end{array}$ & 6 \\
\hline \multirow[t]{3}{*}{ Marketing } & 10 & Marketing & 3 \\
\hline & & Consumer Behavior & 3 \\
\hline & & $\begin{array}{l}\text { Psychology and Sociology } \\
\text { in Management }\end{array}$ & 5 \\
\hline Business Law & 10 & Law & 5 \\
\hline Acquisition and Production & 10 & Logistics & 7 \\
\hline Statistics & 10 & Statistics & 6 \\
\hline \multirow[t]{2}{*}{ Economic Mathematics } & 5 & $\begin{array}{l}\text { Mathematics for } \\
\text { Economists }\end{array}$ & 6 \\
\hline & & Operations Research & 6 \\
\hline \multirow[t]{9}{*}{ Economic Informatics } & 5 & Informatics & 5 \\
\hline & & $\begin{array}{l}4 \text { program-wide electives } \\
\text { (variant): }\end{array}$ & \\
\hline & & Crisis Management & 6 \\
\hline & & Firm Organization & 6 \\
\hline & & Corporate Governance & 6 \\
\hline & & $\begin{array}{l}\text { Management Information } \\
\text { Technology } \\
\end{array}$ & 6 \\
\hline & & $\begin{array}{l}3 \text { school-wide electives } \\
\text { (variant): }\end{array}$ & \\
\hline & & Entrepreneur & 5 \\
\hline & & International Commerce & 3 \\
\hline Subtotal & 110 & Subtotal & 141 \\
\hline \multicolumn{4}{|l|}{ Practice oriented part } \\
\hline Bachelor Colloquium & 10 & \begin{tabular}{|l|}
$\begin{array}{l}\text { Bachelor Seminar } \\
\text { (elective) }\end{array}$ \\
\end{tabular} & 3 \\
\hline $\begin{array}{l}\text { Foundation of the } \\
\text { company and innovation }\end{array}$ & 5 & $\begin{array}{l}\text { Entrepreneurship in small } \\
\text { and medium business }\end{array}$ & 3 \\
\hline $\begin{array}{l}\text { Growth Management and } \\
\text { Internationalization }\end{array}$ & 5 & & \\
\hline Business Cooperations & 5 & & \\
\hline Business Risk & 5 & & \\
\hline Research work & 5 & & \\
\hline Project I & 15 & & \\
\hline Project II & 15 & & \\
\hline \multirow[t]{6}{*}{ Training of social skills } & 5 & & \\
\hline & & Bachelor Thesis Defense & 3 \\
\hline & & $\begin{array}{l}\text { State Bachelor } \\
\text { Examination }\end{array}$ & 3 \\
\hline & & Foreign language 1 & $4 \times 3$ \\
\hline & & \begin{tabular}{|l|} 
Foreign language 2 \\
\end{tabular} & $4 \times 3$ \\
\hline & & \begin{tabular}{|l} 
Vocational subject in \\
foreign language \\
\end{tabular} & 3 \\
\hline Total & 180 & Total & 180 \\
\hline
\end{tabular}

Table 1: Comparison of study programs 
Preparation of managers for the current practice requires corresponding knowledge, that is still less in the domestic academic environment, because the results achieved in practice are not counted in the hunt for impacts. But there is increasing share of academic staff with qualification obtained exclusively within the continuous studies Bachelor-Master-Doctor.

\section{The essence of Management teachings}

The binding of Management on entrepreneurship is common in the business world (Business Management, Business Administration), but with Business Economics at the same level (American, 2015), not as a pendant. But Management is fully applicable in public economics and technical fields, not only on the enterprise but on the organization generally. The basic question what is the essence of Management from a theoretical perspective tried to answer already Harold Koontz (1980), whose textbook of Management significantly influenced the teaching of Management in the Czech Republic (Koontz and Weihrich, 1993). Professor Koontz was not only one of the many authors of books on Management, but the long-time president of the International Academy of Management, a global organization currently helping to develop Management teachings in 114 countries. By him recommended and now the most widely used approach is to establish the Management teachings on typical activities (functions) that are necessary for the organizations generally: planning, organizing, staffing, leading and controlling. These features are unique to the core teaching of Management, but decidedly not theoretical, but rather eclectic ones because the theoretical knowledge is used from a variety of sciences, such as Psychology, Sociology, Economics, Mathematics, Industrial Engineering or System Science.

Although Harold Koontz has been unquestionably one of the gurus of Management, his approach cannot be considered for a universal solution. Joseph L. Massie (1987) added further two functions later - decision making and communicating. Koontz namely included communicating to the function leadership, although he writes, "even though communication accompanies all areas of management, especially for leadership has an extraordinary importance" (Koontz and Weihrich, 1993: 508). Management but without communicating cannot operate at all, only through communicating the entire process is set in motion: manager receives intention or directly goal, completes necessary information, and after selecting a specific alternative solution his decision gets through communicating with subordinates. Even the feedback controlling of realization can be ensured by communicating.

It is also evident that the most important intellectual legacy of Harold Koontz is systemic approach, which is characteristic of his entire textbook. At home, however small response, the functions are declared only, and no system. According to general systems theory is the control a deliberate process of influencing behaviour of the system to achieve a certain goal. Management teachings but can be defined analogically as a mental tool for achieving of goal in the group work. Let us try to characterize the core of Management through the simplified systemic model of goal-oriented behaviour (Figure 1).

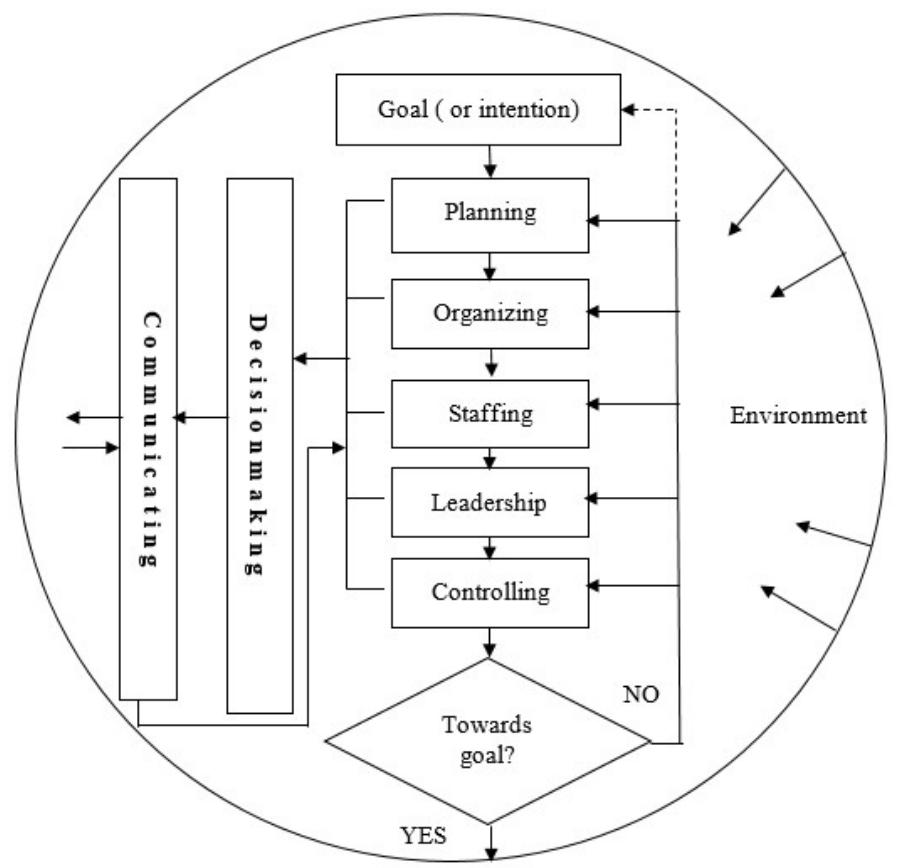

Figure 1: The simplified systemic model of Management (Komárek, 2013)

Planning is not ranked as the first managerial function for its own sake; it is the starting point for achieving the time-distant goal. The goal is communicated to the manager either directly or he has the power to determine it himself according to his intention. To meet the goal, it is necessary to determine the time sequence of corresponding actions, but their identification and coordination in relation to the arrangement of resources is contained in organizing, closely related with planning but different methodically and time independent. The fulfilment of the organization by human resources is staffing, and the essence of leading is influencing subordinates in order to perform tasks as they want (to best) and not only must. Controlling is essentially comparing achieved and desired state (goal, objectives, plans, parameters) and represents a feedback conditioning the function of system with the goal-oriented behaviour in general.

If the check reveals that current state does not ensure the successful achievement of the goal, it is necessary to take appropriate action (e.g. to change terms in plan or to restructure resources, to choose better staff, to change the style of leading, to introduce appropriate controlling or communicating). But there can be a situation that even the best variant of managerial functions does not ensure the achievement of the goal. Why, the goal has been determined incorrectly? Every plan is based on certain assumptions about the future state of environment (both external and internal). But when in the course of implementation the originally anticipated state has changed significantly (mostly beyond our control), the goal must be corrected (and not to waste resources in order to meet the goal "at any cost"). Each of these functions usually contains more variants of solution and therefore it is necessary to determine which one will bring the greatest effect. Decision making is so intertwined with all managerial functions; it is always about choosing the best solution from several options. Therefore decision making has the key role between managerial functions and when some decision is followed by an implementation, the way back may demand a significant cost, loss of authority or may not be possible at all (it is said that managers are paid for making decisions). 
But what are crucial, Business Economics and Management have undergone divergent evolution over fifty years. Business Economics as a description of the corporate functions has unchanged essentially (Wöhe and Döring, 2013), and Management from the original ambiguously defined teachings has developed into number of separate disciplines. The new status as a higher education course and even study program has Strategic, Human resources, Crisis, Risk, Change, Knowledge, Project, Information, Business Process, Operational, Safety, Environmental, Quality and of course Business Management. An economic foundation may have in addition to Business Management also Strategic, Crisis and Risk Managements (if oriented to business), others are based largely on the humanities, systemic and technical sciences. And what was originally conceived as the Management is currently distinguished as the core of Management consisting of its four typical functions (planning, organizing, leadership, controlling) and called General Management (Nieuwenhuizen and Rossouw, 2008: 39). Only in the UK is the General Management defined as a doctrine for top management, but there is also everything different there (and that is why some reformers of the Czech higher education take pattern from there?). General management itself is a sufficient tool for line managers and other managements are actually add-on application of this general principle to a specific area of practice. These specific ones are for the middle-level mainly and the Strategic Management is for the top level. The role of General Management is not limited to the basic organizational level. Whether is a problem in any field of human work, and at any level, its solution requires always setting goals, planning, organizing resources, leading, controlling, and without communication and decision-making cannot work at all.

From the discussion, it is evident that Management is a process which involves designing and maintaining an environment with the main purpose of effectively attaining the chosen goals. The concepts found from these wide ranges of theories are important for managers for them to have an organized but practical knowledge concerning Management. Because for to carry out Management functions, managers have to rely on a number of managerial skills. "The three basic sets of skills which managers have to have are the conceptual, human, and technical skills. Conceptual skills means being able to apply all the above discussed theories of management to fit a given situation they are facing in the organization. Technical skills mean the ability to work and carry out actions which are professional. Finally the manager has to view the members of the organization as human beings who need to be supported in their psychological feelings, needs and emotions" (Kettner, 2002: 145).

\section{Study program Management}

While in Europe the study program Management is classified under Business \& Economics (Bachelorsportal, 2015), independent Bachelor's and Master's degree programs are extended overseas, and common is also Doctoral study program in Management Science. Doctoral studies are a crucial precondition for the autonomy of study program, because it has its own science. The foundations of Management Science are analytical and simulation models for to support decision-making (Operations Research), with emphasis on the methodology of systems modelling and the application of advanced mathematical and statistical methods (The University of Texas, 2015).

Due to the content are essentially analogous to the Management studies also the study programs in Organizational Science and in Administration Science, usually aimed at any kind of organization more generally (The George Washington University, 2015). Orientation in the study programs abroad is not easy, because they are not rigidly arranged (accredited is the institution, not the study program) and they can be considerably individualized by wide selection of elective courses.

There are two different models in principle, the European and the transatlantic ones. Bachelor study in Europe (Bachelorsportal, 2015 ) is usually three years (in the UK also two years) and with respect to Management studies, two approaches are apparent according to the focus. Management of Business is presented mostly as Business Administration and in that the economic basis prevails with varying degrees of orientation to practice (up to domestic interpretations of Bachelor studies as a preparation for immediate Master studies mainly). But significantly different is the Management of non-economic fields, which focuses both on the preparation for specific professional skills and always for line management with respect to anticipated staffing positions in practice. Nota bene the basic condition for the existence of mankind at all is the material production and its distribution, and within them has a decisive proportion the industrial mass production, that requires a mass of line managers in various specializations. Therefore, neither universal manager can be a solution; of crucial importance are just specific Applied Managements.

The transatlantic model (e.g. USA, Canada, and Latin America) is a four-year Bachelor study as a general basis for life-long learning, because there is no exaggerated hunt for the Master degree. The difference in the concept is evident: in the first year compulsory natural sciences (Mathematics, Physics, Chemistry or Biology), optional humanities and social sciences, and Writing and Rhetoric (The MIT Sloan School of Management, 2015). The managers in the industrial society control the human-machine systems and therefore the importance of Physics (Mechanics, Electricity) for the study of Management. If degree programs in Management are not focused on business (e.g. Management Science and Engineering), economic courses are just additional as elective ones, and no pure theory, but Economic Analysis or Accounting (Stanford University, 2015). Another fundamental difference is that so conceived Bachelor study is sufficient for entering Doctoral study. This is one of the factors of the high efficiency of this model, and ultimately also of the competitiveness at all. The broad general basis significantly promotes flexibility of the entire educational system, because the Master study may be more interdisciplinary than domestic rigid link to the original Bachelor field of study. This is typical for the Master study in Project Management or in Human Resources Management that can follow after any Bachelor field of study, which is still possible also in Europe (Masterstudies. com, 2015).

\section{Conclusion}

Some change can bring the intended transfer of accreditation competencies on the educational institutions, which would give more flexibility in creating programs to the needs of socialeconomic practice. Although is the study program Management expected next Business Economics (Návrh Nařízení vlády, 2015), the question is what demands will result from affiliation to the economic science, especially for Applied Management (Basics of Economics or Business Economics?). But when regarding content of all foreseen Areas of Education (Návrh Nařizení vlády, 2015), there is no good news for the domestic practice 
there. Primarily are not distinguished undoubtedly different requirements for professionally oriented or academic study programs. Furthermore, the content of each Area of Education is not formally unified, even though its structure (education descriptors), has been unambiguously defined in the project Q-Ram (Černikovský et al., 2012). But what is significant: in almost all fields with an outlet to practice is referred to the applicable range of Bachelor graduates for elementary to middle level management, but no mention of adequate managerial skills. It seems that will be still a long way to increasing the efficiency of higher education regarding the needs of current, and especially future practice.

\section{Acknowledgements}

This paper has been funded by the Operational Program Education for Competitiveness within the project CZ.1.07/2.2.00/28.0010 Innovation of teaching at the Karel Englis College across the fields of study in order to enhance the quality and to reinforce the competitiveness of the college and its students.

\section{References}

Akreditační komise (2013) Standardy Akreditační komise pro studijní programy z oblasti aplikovaného managementu. [Online], Available: http://www.akreditacnikomise.cz/ attachments/article/459/Management.pdf [24 Okt 2014].

American Economic Association (2015) JEL Classification Codes Guide, [Online], Available: https://www.aeaweb.org/jel/ guide/jel.php [16 Apr 2015].

Bachelorsportal.eu (2015) Bachelor's Degree in Management \& Organization, [Online], Available: http://www.bachelorsportal. eu/disciplines/89/management-organisation.html [15 Apr 2015]. Business School Berlin Potsdam (2009) Modulübersicht Business Administration, [Online], Available: http://www. businessschool-berlin-potsdam.de/bachelorstudiengaenge/ business-administration/studium/moduluebersicht $\left[\begin{array}{ll}22 & \text { Sep }\end{array}\right.$ 2014].

Co nejvíc trápí české manažery? Školství. (2013), Moderní řízení, vol. 48, no. 4, pp. 6-7.

Černikovský, P. et al. (2012) Národni kvalifikační rámec vzdělávání, Díl 2. Oblasti vzdělávání. Praha: MŠMT.

Fakulta podnikohospodářská (2014) Vzorový studijní plán bakalářského studia oboru Podniková ekonomika a management pro studenty prijímané do akademického roku 2014/2015, [Online], Available: http://fph.vse.cz/studenti/ bakalarske-studium/bakalarsky-obor-podnikova-ekonomikaa-management/studijni-plan-pro-akademicky-rok-20142015/ vzorovy-studijni-plan-skupiny-a/ [24 May 2015].

Hamel, G. (2009) 'Moon shots for Management', Harvard Business Review, no. 2, pp. 1-9.

Kettner P. (2002) Achieving excellence in the management of human service organizations, Boston: Allyn \&Bacon publishers. Komárek, J. (2013) 'Current trends of Management learning', The 2nd International Conference Current social and economic issues of European society, Brno: Karel Englis College, pp. 6671.

Komárek, J. (2014) 'Kontradikce podnikové ekonomiky a managementu', The 3rd International Conference Current social and economic issues of European society. Brno: Karel Englis College, pp. 49-55.

Koontz, H. (1980) 'The Management Theory Jungle Revisited', Academy of Management Review, vol. 8, no. 2, pp. 175-187.

Koontz, H. and Weihrich, H. (1993) Management, Praha: Victoria Publishing.
Košturiak, J. (2006) 'Česká škola managementu', Moderní rízení, vol. 41, no. 1, pp. 6-7.

Massie, J. L. (1987) Essentials of Management, 4th edition, New Jersey: Prentice Hall.

Masterstudies.com (2015) Compare Top Masters Programs in Europe 2015/2016, [Online], Available: http://www. masterstudies.com/Masters-Degree/Europe/ [10 May 2015].

Návrh Nařizeni vlády o vymezeni oblastí vzdělávání (2015) Praha: Vláda České republiky.

Nieuwenhuizen, C. and Rossouw, D. (2008) 'Chapter 2. General Management', Business Management - A Contemporary Approach, Cape Town: Juta and Co.

Souček, Z. (2012) 'Oddělme zrno od plev', Moderní řízení, vol. 47, no. 9, pp. 6-9.

Stanford University (2015) Bachelor of Science in Management Science and Engineering, [Online], Available: http:// exploredegrees.stanford.edu/schoolofengineering/management scienceandengineering/\#bachelorstext [12 May 2015].

The George Washington University (2015) Organizational sciences, [Online], Available: http://orgsci.columbian.gwu.edu/ organizational-sciences [21 Apr 2015].

The MIT Sloan School of Management (2015) Major in Management Science, [Online], Available: http://mitsloan. mit.edu/undergrad/major-and-minors/major-in-managementscience/ [10 May 2015].

The University of Texas in Dallas (2015) Management Science PhD Degree Plan, [Online], Available: http://jindal.utdallas. edu/phd-programs/management-science/degree-plan/ [20 Apr 2015].

Úlovec, M. (2014) Potřeby zaměstnavatelů a prripravenost absolventů škol - komparační analýza, Praha: Národní ústav pro vzdělávání.

Wöhe, G. (1960) Einführung in die Allgemeine Betriebswirtschaftslehre, München: Verlag Franz Vahlen.

Wöhe, G. and Döring, U. (2013) Einführung in die Allgemeine Betriebswirtschaftslehre, 25th Edition, München: Verlag Franz Vahlen. 